Historic, archived document

Do not assume content reflects current scientific knowledge, policies, or practices. 

United States

Department of

Agriculture

Forest Service

Pacific Northwest

Research Station

Research Paper

PNW-RP-443

May 1992

近出

\section{Dispersal of White Spruce Seed on Willow Island in Interior Alaska}

Andrew Youngblood and Timothy A. Max

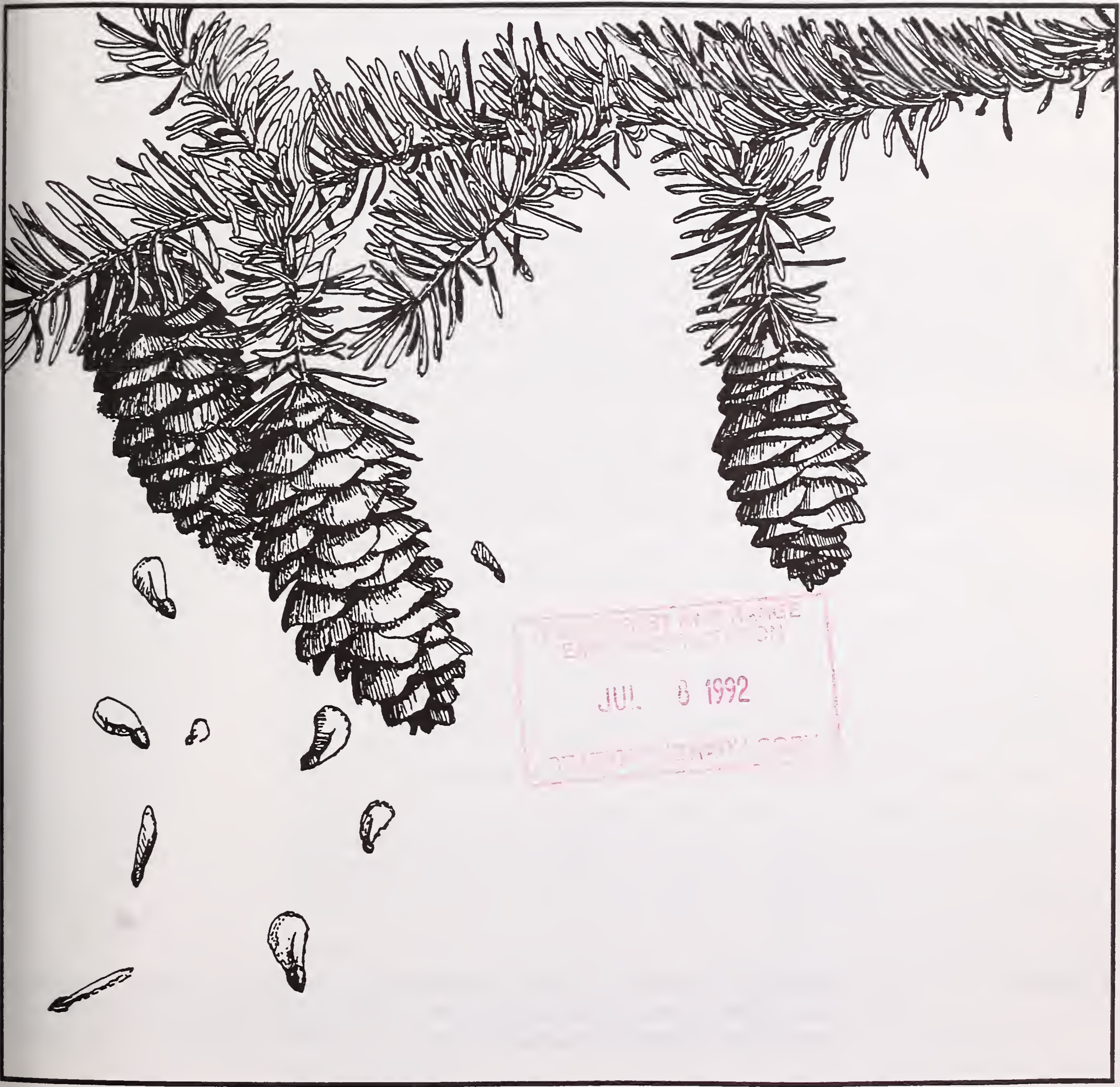




\section{Abstract}

Summary
Youngblood, Andrew; Max, Timothy A. 1992. Dispersal of white spruce seed on Willow Island in interior Alaska. Res. Pap. PNW-RP-443. Portland, OR: U.S. Department of Agriculture, Forest Service, Pacific Northwest Research Station. $17 \mathrm{p}$.

The seasonal and spatial patterns of dispersal of white spruce (Picea glauca (Moench) Voss) seed were studied from 1986 to 1989 in floodplain stands along the Tanana River near Fairbanks, Alaska. Analysis of the 1987 crop showed that production of filled seed was strongly related to estimated production of total seed and unrelated to selected stand structural characteristics. A mathematical expression, developed to estimate dispersal of filled seed into clearcut openings, predicted dispersal between 10 and 120 meters from the edge of an opening. The pattern of wind during the seed-dispersal season was predictable and consistent with winds measured at the Fairbanks International Airport. The results give forest managers ways to increase natural regeneration of white spruce in interior Alaska.

Keywords: White spruce, Picea glauca, dispersal of seed, Alaska (interior), production of seed, wind pattern.

Production and dispersal of white spruce seed were studied from August 1986 through May 1989 on Willow Island, a large floodplain island in the Tanana River southwest of Fairbanks, Alaska. Production of seed was observed in undisturbed stands surrounding three clearcut harvest units and in four shelterwood stands. Basal area of white spruce in undisturbed stands ranged from 9 to 25 square meters per hectare. Shelterwood stands ranged from 5 to 11 square meters per hectare in basal area retained from a uniform seed cut conducted in 1983.

Seed traps were placed in seed source areas surrounding clearcut units and randomly within shelterwood stands. Traps also were placed at measured intervals along transects extending into clearcut harvest units. Traps were emptied periodically throughout the dispersal period, and seed was tested for soundness.

Speed and direction of wind at tree canopy height was monitored during the dispersal period from an instrumented tower erected in the center of one clearcut unit.

Production of seed was a failure in 1986 and 1988. Mean production from 11 source areas in 1987 was 1,340 total seeds per square meter and 390 filled seeds per square meter, which ranked high when compared to records from previous years.

The ratio of filled seed to total seed produced in seed source areas was estimated to be 0.29 . Total quantity and quality of seed differed throughout the dispersal season. More than 75 percent of the filled seed fell before mid-October. Production of seed and five stand structural characteristics in seed source areas were not related.

Nonlinear equations were developed to model dispersal of filled seed into clearcut openings. The shape of the dispersal curve was similar across most units, although seed source areas differed greatly in production. Negative exponential models suggested that seed for natural regeneration on prepared sites may be adequate up to 120 meters from the clearing edge in years of similar production of seed.

Production of total and filled seed in shelterwood stands was similar to that in uncut source areas, when the reduced basal area was taken into account. The seasonal distribution of seed fall was similar to that of undisturbed stands.

Most winds during the seed-dispersal season were from either the northeast or south-southwest. 
Contents

$\begin{aligned} 1 & \text { Introduction } \\ 2 & \text { Methods } \\ 2 & \text { Description of Study Area } \\ 2 & \text { Collection and Quantification of Seed } \\ 5 & \text { Wind Patterns } \\ 5 & \text { Results and Discussion } \\ 5 & \text { Seed Fall in Uncut Stands } \\ 9 & \text { Dispersal of Seed in Clearcut Units } \\ 12 & \text { Seed Fall in Shelterwood Stands } \\ 12 & \text { Seasonal Wind Patterns } \\ 15 & \text { Recommendations } \\ 15 & \text { Conclusions } \\ 15 & \text { Acknowledgments } \\ 15 & \text { Literature Cited }\end{aligned}$


Current forest management plans indicate much of the area supporting white spruce (Picea glauca (Moench) Voss) in interior Alaska will be reforested by natural regeneration after timber harvest (State of Alaska 1988). White spruce stands normally lack advance regeneration. Thus, for natural regeneration to be successful, seed must be dispersed from adjacent stands into clearcut openings or from trees on the site retained for production of seed. This paper provides estimates of production and dispersal of seed into harvest units for floodplain stands in interior Alaska.

Irregular production of white spruce cone and seed in interior Alaska upland stands has been observed by Zasada (1980). During one 10-year period, seed fall for one white spruce stand exceeded 400 seeds per square meter in 4 of these years. Factors leading to low production of seed in intervening years include environmental variables (particularly temperature during cone initiation), nutrient deficiencies, insects, disease, and squirrels (Alden 1985, Nienstaedt and Teich 1972, Zasada 1980, Zasada and others 1978).

The seasonal pattern of dispersal of seed on upland sites in interior Alaska is well documented (Zasada 1985, Zasada and Viereck 1970, Zasada and others 1978): seed is first released in late August or early September, 90 percent of the seed fall occurs by the end of December, and sporadic seed fall continues through April and May.

Wind is the primary agent for dispersal of white spruce seed (Zasada and Lovig 1983). The distance an individual seed is transported is a function of speed and direction of wind, air turbulence, cone height, and seed wing structure. Dobbs (1976) found over 100 seeds per square meter at 200 meters from a seed source area in central British Columbia and suggested that significant quantities of seed are released in high winds. He estimated seed soundness, based on a small subsample, was 48 percent for the first and 31 percent for the next 100 meters from stand edge. On three different upland sites near Fairbanks, Alaska, Zasada (1985) observed 68, 23, and 8 seeds per square meter at 100 meters from the source areas; viability was about 62 percent.

White spruce stands on interior Alaska floodplains differ from upland stands in available solar radiation, in both air and soil temperature (Slaughter and Viereck 1986), and in forest development (Viereck and others 1986). Little is known of production and dispersal of seed in floodplain stands or of the effects of different harvest cutting methods on production of seed.

Objectives of this study were as follows:

1. To describe quantity and quality of seed crop in floodplain stands.

2. To determine the relation between production of seed in source areas and the distance seed is dispersed into openings.

3. To describe the pattern of wind when seed is dispersed.

4. To describe harvest unit size and shape based on dispersal of seed for successful natural regeneration of white spruce. 


\section{Methods}

Description of Study Area

Collection and Quantification of Seed
Work was conducted on Willow Island, a 200-hectare island in the Tanana River floodplain, 32 kilometers southwest of Fairbanks, Alaska (fig. 1). The island is 123 meters above mean sea level, with a topographic relief of 2 meters. Floodplain terrain surrounds the island; the closest hills are 7 kilometers to the north. Climate of the study area is strongly continental, with mean daily temperature in January below $-20^{\circ} \mathrm{C}$, an average of 214 days continuous snow cover, and mean daily temperature in July of $17^{\circ} \mathrm{C}$ (Slaughter and Viereck 1986).

Homogeneous units of vegetation and soils on Willow Island were mapped and characterized before timber harvesting (Dyrness and others 1988). Eleven stands representing three different vegetation types were used as seed source areas (table 1). In addition, four shelterwood harvest units in two of the vegetation types were used as examples of manipulated stands. The Open Picea glauca/Alnus crispa-Alnus tenuifolia/Vaccinium vitis-idaea/Hylocomium splendens type contained a 30- to 50percent overstory canopy cover primarily in white spruce. Dominant and codominant white spruce ranged in age at breast height from 130 to over 350 years. Scattered paper birch (Betula papyrifera Marsh.) also occurred in different amounts. Stands in the Closed Picea glauca/Alnus tenuifolia/Hylocomium splendens type contained a 55- to 70-percent overstory canopy cover of white spruce and scattered balsam poplar (Populus balsamifera L.) and paper birch. White spruce were 120 to 150 years old. In contrast, total tree overstory canopy cover in the Open Picea glauca/Alnus tenuifolia/Hylocomium splendens vegetation type ranged from 30 to 60 percent and was primarily white spruce with minor amounts of balsam poplar. In these stands, white spruce was 110 to 150 years old.

Production of seed was observed in undisturbed stands surrounding three clearcut harvest units and within four shelterwood harvest units. Harvest units (fig. 1) are described in more detail by Dyrness and others (1988) and Youngblood and Zasada (1991). Seed source areas surrounding clearcut units were at cardinal directions from the center of each unit; unit 9 had seed source areas on the north, south, and west sides only. Four source areas were blocks of at least 3 hectares with 50-meter-wide strips serving as the remaining seven source areas (table 1). Three seed traps were placed flat on the ground 10 meters apart and 10 meters from the stand boundary within each source area. Each trap was 0.5 by 0.5 meter and consisted of a 10centimeter-high wooden frame with screen bottom, muslin lining, and 1-centimeter hardware cloth cover. Two traps also were placed 10 meters apart along transects extending into clearcut harvest units at 10, 20,30, 40,50,60, 76, 91, and 122 meters from the edge of each seed source area. All seed collected in traps along transects was assumed to be from the source area where the transect originated. Six seed traps were randomly placed near the center of each shelterwood harvest unit. Traps were installed in mid-August, and production of seed was observed for 3 years beginning in 1986. Traps were cleaned in mid-September, mid-October, and after snowmelt the following spring. The number of filled seeds (seeds with a welldeveloped megagametophyte) were counted after each seed was bisected. 


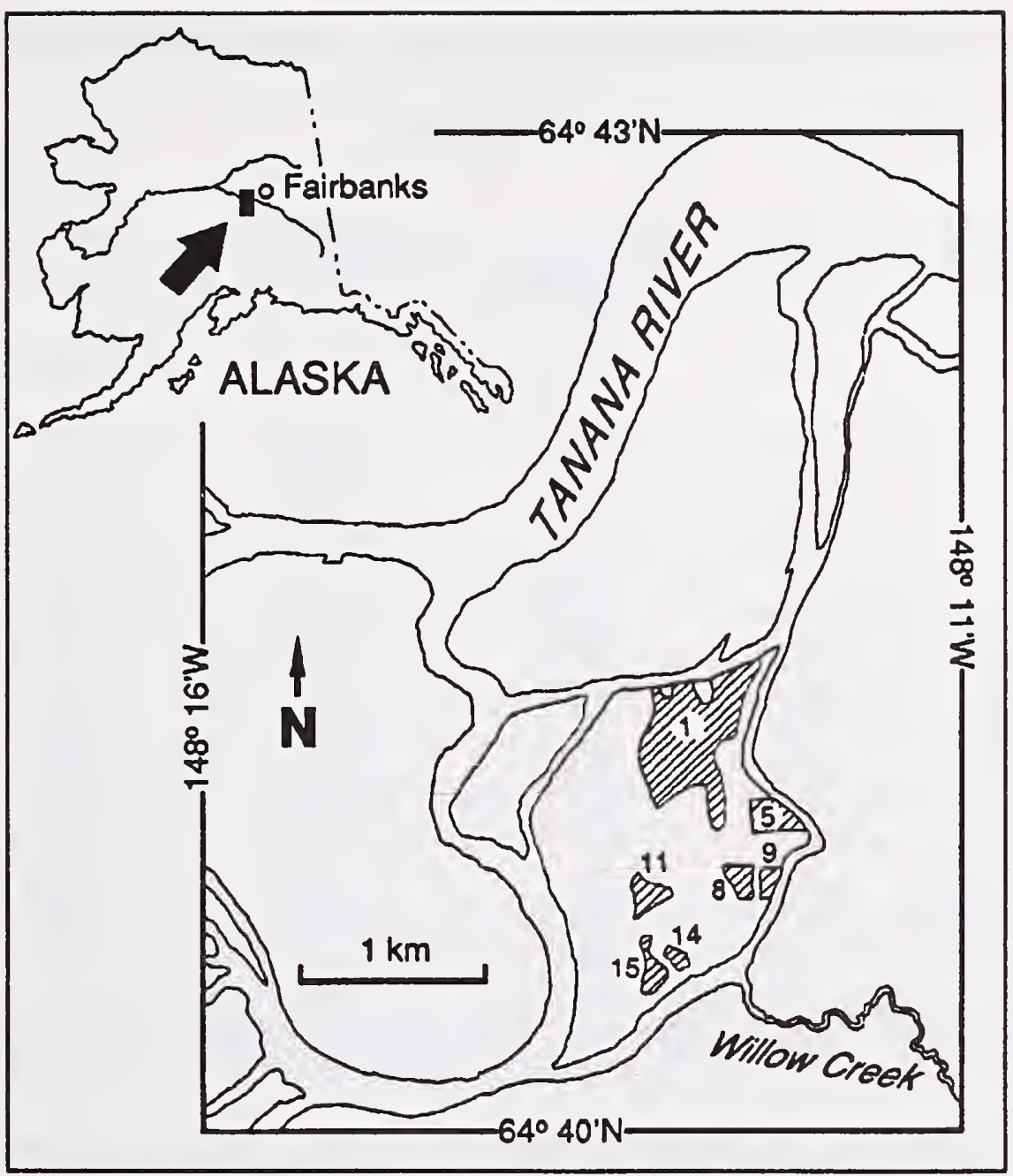

Figure 1-Location of harvest units containing seed trap transects on Willow Island in the Tanana River near Fairbanks, Alaska.

The ratio of filled seed per square meter to total seed per square meter within seed source areas was estimated for 1987. Plots of mean number of total seeds per square meter versus the mean number of filled seeds per square meter indicated a linear relation passing near the origin. The relation logically should pass through the origin because if total seed production is zero, then production of filled seed also is zero. Based on these plots, a ratio of means estimator (Cochran 1977, Krishnaiah and Rao 1988) was selected,

$$
R=Y / X
$$

where

$R=$ the estimated ratio,

$Y=$ the sample mean of number of filled seed per square meter, and

$X=$ the sample mean of number of total seed per square meter.

The ratio was estimated from 11 observations. Each observation was the total seed count and all filled seed collected throughout the year and was based on the average of the three traps placed within the stand at the beginning of each transect line. The standard error of R was estimated by using a jackknife estimator (Cochran 1977) because sample size $(n=11)$ was small. The jackknife estimator was selected to reduce bias in the estimated standard error. 
Table 1-Stand characteristics in seed production stands on Willow Island, Alaska

\begin{tabular}{|c|c|c|c|c|c|c|c|c|}
\hline \multirow[b]{2}{*}{$\begin{array}{l}\text { Source } \\
\text { area }\end{array}$} & \multirow[b]{2}{*}{$\begin{array}{l}\text { Vegetation } \\
\text { type } e^{a}\end{array}$} & \multirow[b]{2}{*}{$\begin{array}{l}\text { Stand } \\
\text { size }\end{array}$} & \multicolumn{3}{|c|}{ Living white spruce } & \multicolumn{3}{|c|}{ Total in stand ${ }^{c}$} \\
\hline & & & $\begin{array}{c}\text { Basal } \\
\text { area }\end{array}$ & Diameter & $\begin{array}{c}\text { Number } \\
\text { per hectare }\end{array}$ & Height $^{d}$ & $\begin{array}{l}\text { Basal } \\
\text { area }\end{array}$ & $\begin{array}{c}\text { Number } \\
\text { per hectare }\end{array}$ \\
\hline & & & $m^{2} \cdot h a^{-1}$ & $\mathrm{~cm}$ & & meters & $m^{2} \cdot h a^{-1}$ & \\
\hline $\begin{array}{l}1-N \\
1-S \\
1-E \\
1-W \\
9-N \\
9-S \\
9-W \\
15-N \\
15-S \\
15-E \\
15-W \\
5 \\
8 \\
11 \\
14\end{array}$ & $\begin{array}{l}1 \\
1 \\
1 \\
2 \\
1 \\
1 \\
1 \\
3 \\
2 \\
3 \\
3 \\
1 \\
1 \\
3 \\
3\end{array}$ & $\begin{array}{l}\text { S } \\
B \\
\text { S } \\
B \\
\text { S } \\
B \\
\text { S } \\
\text { S } \\
\text { S } \\
\text { S } \\
\text { B } \\
\text { Sw } \\
\text { Sw } \\
\text { Sw } \\
\text { Sw }\end{array}$ & $\begin{array}{r}15.4 \\
8.6 \\
23.1 \\
23.6 \\
30.5 \\
25.0 \\
13.9 \\
26.4 \\
25.3 \\
25.9 \\
27.6 \\
9.1 \\
5.5 \\
10.6 \\
4.8\end{array}$ & $\begin{array}{l}14.9 \\
15.9 \\
13.1 \\
11.9 \\
27.4 \\
29.6 \\
21.8 \\
22.2 \\
28.7 \\
29.1 \\
25.5 \\
37.3 \\
25.7 \\
34.8 \\
22.3\end{array}$ & $\begin{array}{r}803 \\
352 \\
1,508 \\
1,801 \\
470 \\
313 \\
333 \\
627 \\
352 \\
352 \\
333 \\
80 \\
107 \\
107 \\
107\end{array}$ & $\begin{array}{l}18.9 \\
20.1 \\
19.8 \\
17.7 \\
26.4 \\
30.7 \\
20.4 \\
23.6 \\
28.4 \\
29.6 \\
29.4 \\
30.0 \\
20.0 \\
25.0 \\
26.1\end{array}$ & $\begin{array}{r}19.8 \\
11.3 \\
26.1 \\
25.2 \\
35.5 \\
34.5 \\
18.7 \\
27.4 \\
25.3 \\
26.6 \\
28.9 \\
21.1 \\
5.5 \\
10.6 \\
4.8\end{array}$ & $\begin{array}{r}1,175 \\
568 \\
1,723 \\
2,154 \\
529 \\
411 \\
529 \\
685 \\
352 \\
372 \\
529 \\
187 \\
107 \\
107 \\
107\end{array}$ \\
\hline
\end{tabular}

\footnotetext{
${ }^{a}$ Vegetation types: 1 = Open Picea glauca/Alnus crispa-Alnus tenuifolia/Vaccinium vitis-idaea/Hylocomium splendens, $2=$ Closed Picea glauca/AInus tenuifolia/Hylocomium splendens, 3 = Open Picea glauca/Alnus tenuifolia/Hylocomium splendens as described by Dyrness and others (1988).

${ }^{b}$ Stand size: $\mathrm{S}=$ strips less than 50 meters wide, $\mathrm{B}=$ blocks 3 hectares or more, $\mathrm{SW}=2.5$ hectare shelterwood units.

${ }^{\circ}$ Includes dead white spruce and all hardwoods.

${ }^{d}$ Mean height of dominant white spruce.
}

Stand inventory data were collected for each source area and used to compute stand and tree parameters for relating sound seed production to tree or stand structural characteristics. We computed linear correlation coefficients between production of filled seed and the following five measured stand characteristics: (1) total basal area, (2) basal area of white spruce, (3) number of living white spruce stems per hectare, (4) average diameter at breast height (d.b.h.) of all trees, and (5) average height of dominant trees. We then plotted production of seed against each stand characteristic variable to visually check for any strong relation that may have been nonlinear and thus not detected by the correlation analyses.

Nonlinear regression was used to model the relation of amount of seed dispersed into an opening as a function of distance from the seed source. The dependent variable was the ratio of amount of filled seed observed at any specified distance from the stand edge to the amount of filled seed produced within the stand during the 1987 seed year. The independent variable was distance from edge of the forest stand to the seed trap in the opening. Plots of these data revealed heteroscedasticity in the variation of the dependent variable. Visual inspection of graphs of the data indicated that variance of the dependent variable was approximately inversely related to square root of distance. Estimates of regression parameters were obtained by using the Gauss-Newton algorithm with square root of distance selected as the weighting factor. Data from all transect lines were combined for this analysis to fit a relation that would be applicable to stands similar to the ones represented in this sample. 
The negative exponential model for dispersal of seed had the following form:

$$
Y=b_{0} \exp \left(b_{1} X\right) \text {. }
$$

where

$Y=$ the ratio of filled seed dispersed at distance $X$ to filled seed produced within the source stand,

$X=$ distance from seed source, and

$b_{0}$ and $b_{1}=$ regression coefficients.

We estimated this model as presented and also with bo set to 1.0 .

Wind Patterns

\section{Results and} Discussion

\author{
Seed Fall in \\ Uncut Stands
}

Speed and direction of wind at 25 meters aboveground (canopy height) were determined for the center of the largest clearcut unit. The tower was more than 210 meters from the closest undisturbed stand. Speed of wind was measured with a helicoid-shaped propeller with 0.7-meter-per-second sensitivity; direction of wind was measured with a vane of 0.5 -meter-per-second sensitivity. Recordings were made at 5-minute intervals; vectors were summed for each hour and then output to a multichannel data logger. Recording began when seed traps were installed each year in mid-August and extended through the seed-collection period.

Hourly vector direction was summed for each 24 -hour day; hourly vector magnitude was averaged across each 24-hour day. Local climatological data for the Fairbanks International Airport were obtained for the same period from the National Weather Service. Directional frequency and average speed of wind at both locations during dispersal of seed are presented graphically later in this paper.

White spruce seed was collected in all three seed years. The total seed fall differed among years. The 1986 seed fall was 48 seeds in 241 traps distributed within or adjacent to seven harvest units; 23,336 seeds were collected for 1987 , and 104 seeds for 1988. Both 1986 and 1988 are seed crop failures and are hereafter not discussed.

Both total seed fall and filled seed differed substantially across the study area (table 2). The highest estimated total white spruce seed fall in undisturbed stands was almost 3,700 seeds per square meter (source area 9-N). This production was similar to the best seed year recorded for interior Alaska, 1958, when total seed fall in one stand was 4,000 seeds per square meter and the quantity of viable seed was 2,600 per square meter (Zasada 1980, 1985). The lowest estimated seed fall in undisturbed stands was nearly 440 seeds per square meter (source area $15-\mathrm{N}$ ). Even this estimate of seed production ranked high in comparison with long-term records of seed production for interior Alaska.

The estimated ratio of filled seed to total seed produced in each stand for 1987 was 0.29 with a standard error of 0.02 . This ratio will probably be useful for estimating number of filled seed per square meter only for years in which the total seed crop is comparable to that observed in this study (range of $\mathbf{4 4 0}$ to 3,700 total seeds per square meter) and for similar stands. 
Table 2-Production of total and filled white spruce seed per square meter by seed source area on Willow Island for $1987(n=3)$

\begin{tabular}{lrrrrr}
\hline $\begin{array}{l}\text { Source } \\
\text { area }\end{array}$ & $\begin{array}{r}\text { Total } \\
\text { seed }\end{array}$ & SE & $\begin{array}{l}\text { Filled } \\
\text { seed }\end{array}$ & SE & $\begin{array}{r}\text { Percent } \\
\text { of total }\end{array}$ \\
\hline $1-\mathrm{N}$ & 944 & 90 & 381 & 34 & 40 \\
$1-\mathrm{S}$ & 625 & 128 & 199 & 58 & 32 \\
$1-\mathrm{E}$ & 1,204 & 170 & 356 & 35 & 30 \\
$1-\mathrm{W}$ & 980 & 140 & 428 & 75 & 44 \\
$9-\mathrm{N}$ & 3,676 & 150 & 951 & 91 & 26 \\
$9-\mathrm{S}$ & 1,755 & 379 & 469 & 99 & 27 \\
$9-\mathrm{W}$ & 2,720 & 636 & 716 & 245 & 26 \\
$15-\mathrm{N}$ & 437 & 52 & 125 & 12 & 29 \\
$15-\mathrm{S}$ & 860 & 146 & 183 & 13 & 21 \\
$15-\mathrm{E}$ & 852 & 71 & 369 & 35 & 43 \\
$15-\mathrm{S}$ & 648 & 61 & 121 & 17 & 19 \\
\hline
\end{tabular}

Production of filled seed was substantially less than that noted in nearby upland stands in both 1958 and 1983, when nearly 60 percent of the seeds were filled (Zasada 1985); production of seed in upland stands for 1987 was not monitored. Several factors can affect seed quality: white spruce is susceptible to frost damage in this portion of its distribution; floodplain or river-bottom stands often incur more damage from late May frost than do upland stands (Zasada 1971); white spruce seed loss to insects, especially to the spruce seed chalcid (Megastigmus pineae Rohwer (M. atedius Walker)) and the spruce seed midge (Mayetiola carpophage Tripp) (Alden 1985, Werner 1964); the red squirrel (Tamiasciurus hudsonicus Erxleben) harvests white spruce cones within individual territories and may account for local losses.

Correlation coefficients for production of filled seed and five stand structural characteristics are presented in table 3 . None was significant. The highest correlation was 0.30 for the stand characteristic total basal area $(p \leq 0.37)$. In addition, plots of these data did not reveal any nonlinear relations between seed production and any of the five stand characteristics. These data suggest the absence of any predictable relation between the structural characteristics examined and production of filled seed. Stand structure and tree physiology are probably important in controlling formation of flower buds, but production of seed is probably affected more by environmental factors, such as weather and insects, and is more difficult to predict.

Seed that fell early in the season was generally of higher quality than seed that fell later (fig. 2). More than 75 percent of the filled seed collected from all 11 seed source areas fell before mid-October. Only 17 percent of the seed collected after mid-October was filled, although more than 40 percent of all seed fell after this date. This relation is similar to that reported by Dobbs (1976) and Zasada and Viereck (1970). A notable exception was the four source areas surrounding cutting unit 15; dispersal of filled seed was more evenly distributed through the three collection periods. 
Table 3-Correlation coefficients and their $p$-values reiating stand structural characteristics to filled seed production in 11 stands on Wiliow Isiand in 1987

\begin{tabular}{lcr}
\hline Structural characteristic & $\begin{array}{c}\text { Correlation } \\
\text { coefficient }\end{array}$ & p-value \\
\hline Total basal area per hectare & 0.30 & 0.37 \\
White spruce basal area per hectare & .09 & .79 \\
Number stems per hectare & .00 & .99 \\
Average stem diameter & .13 & .69 \\
Height of dominant white spruce & -.06 & .86 \\
\hline
\end{tabular}
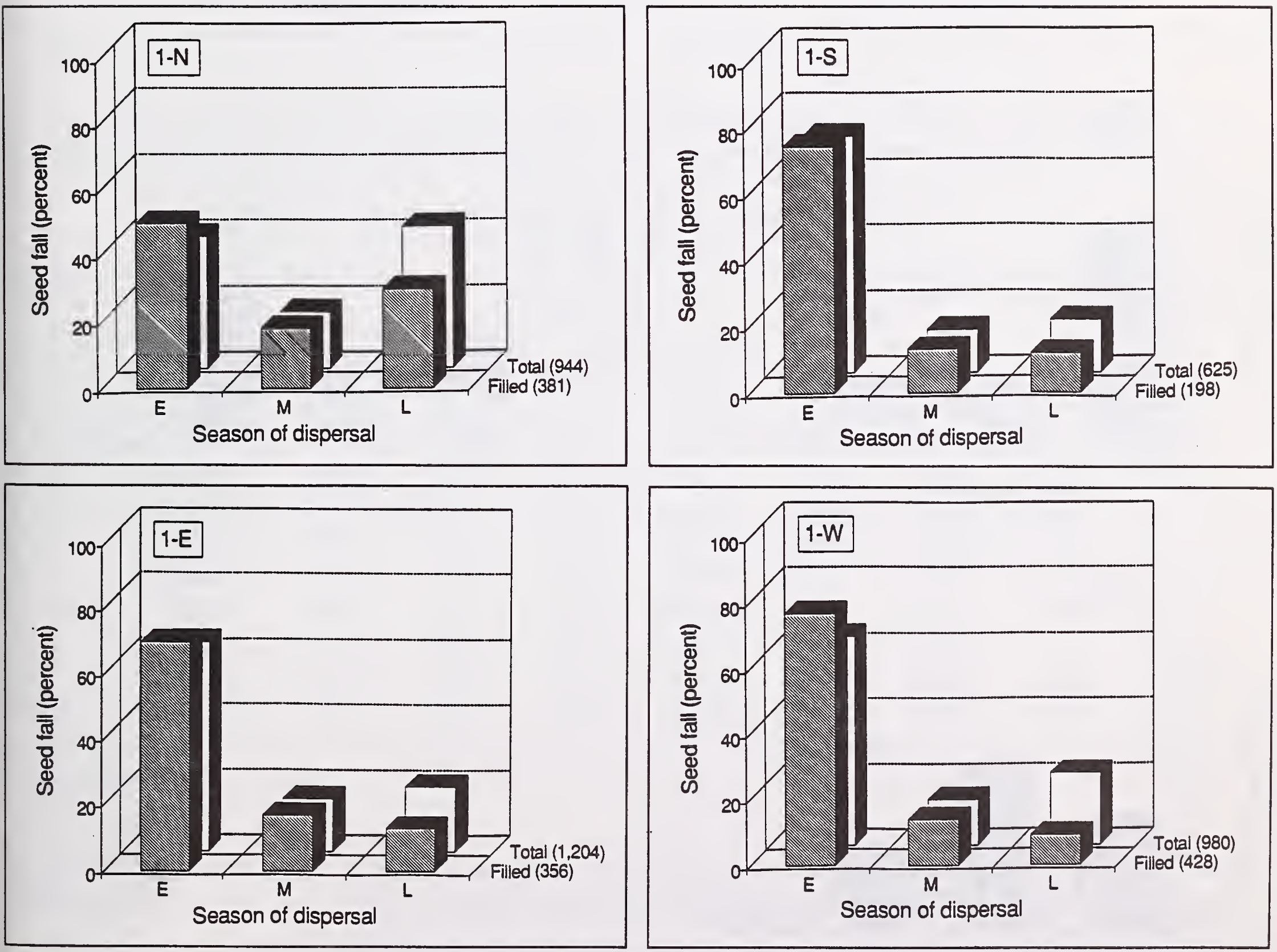

Figure 2-Timing of dispersal of white spruce seed for total and filled seeds, expressed as a percentage, for 11 seed source areas on Willow Island in 1987. Numbers in parentheses are basis, in seeds per square meter. $E=$ mid-August to mid-September; $M=$ mid-September to midOctober; $L=$ mid-October to May. 

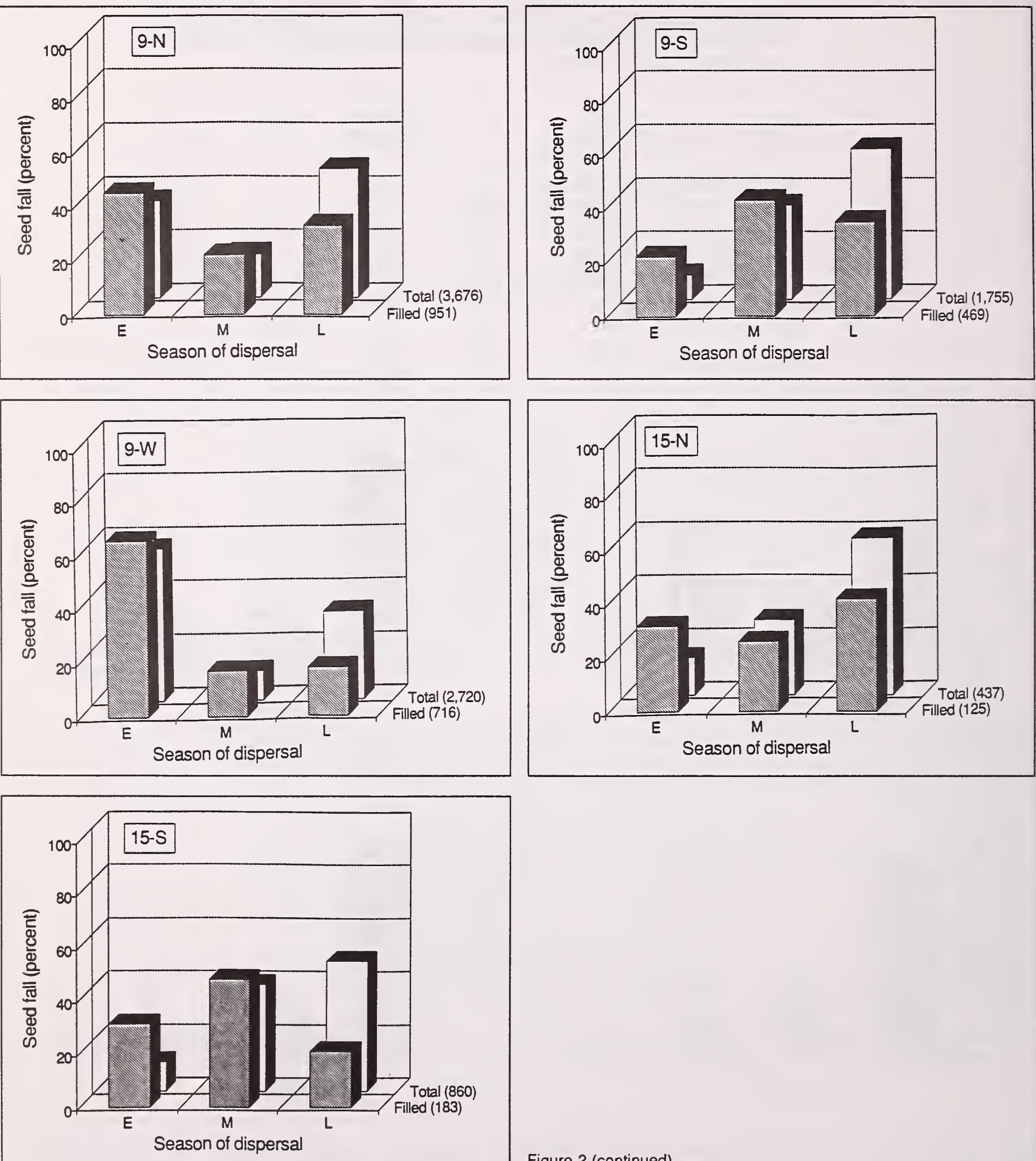

Figure 2 (continued) 

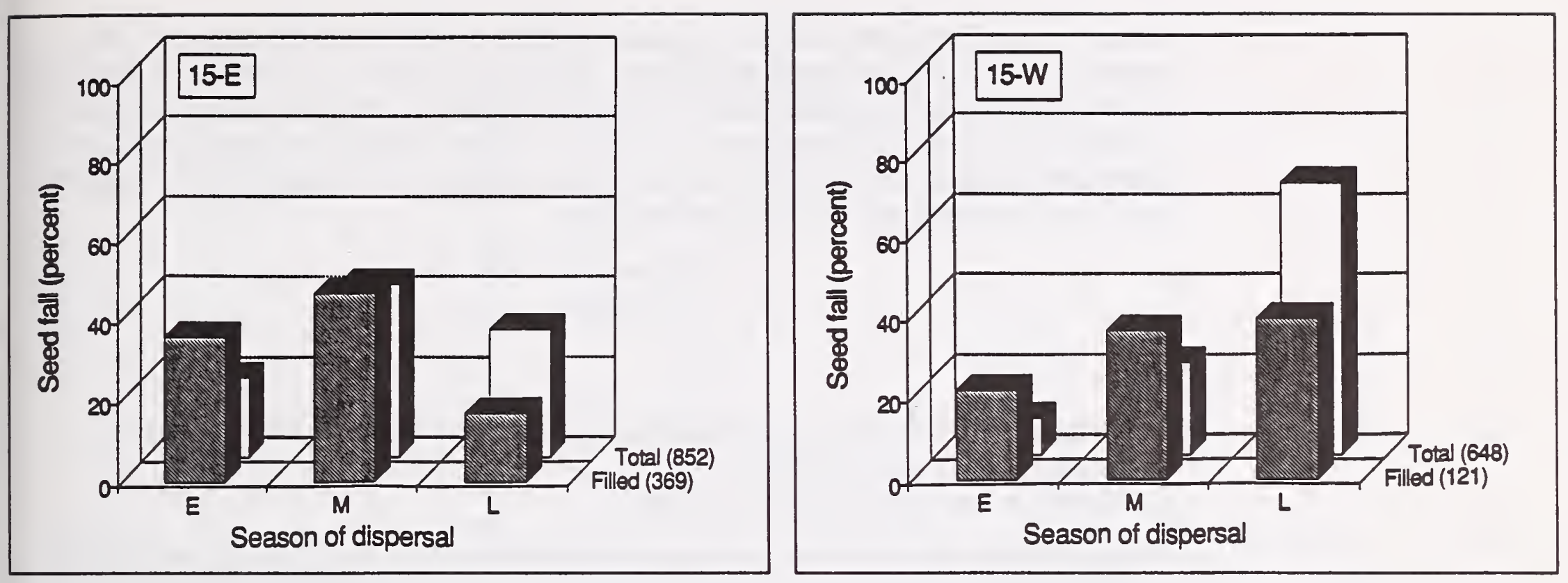

Figure 2 (continued)

Table 4-Mean number of filied white spruce seed (and percentage of ail seed) per square meter dispersed along transects In cleared openings, by seed source area, on Willow island for 1987

Number of filled seed (and percentage of all seed) dispersed into openings by distance from source in meters

\begin{tabular}{|c|c|c|c|c|c|c|c|c|c|}
\hline $\begin{array}{l}\text { source } \\
\text { area }\end{array}$ & 10 & 20 & 30 & 40 & 50 & 60 & 76 & 91 & 122 \\
\hline $1-N$ & $30(41)$ & $42(62)$ & $12(50)$ & $38(58)$ & $16(57)$ & $24(48)$ & $46(49)$ & $20(63)$ & $30(50)$ \\
\hline $1 . S$ & $36(47)$ & $22(79)$ & $10(55)$ & $8(80)$ & $44(59)$ & $20(38)$ & $36(55)$ & $34(41)$ & $20(50)$ \\
\hline $1-E$ & $86(66)$ & $14(33)$ & $24(27)$ & $38(56)$ & $50(49)$ & $68(41)$ & $38(31)$ & $24(22)$ & $34(61)$ \\
\hline $1-W$ & $270(50)$ & $36(53)$ & $86(62)$ & $38(43)$ & $58(51)$ & $14(64)$ & $48(39)$ & $78(63)$ & $48(77)$ \\
\hline $9-N$ & $444(34)$ & $318(33)$ & $258(38)$ & $244(52)$ & $234(44)$ & $178(48)$ & $152(42)$ & $148(33)$ & - \\
\hline 9.5 & $186(35)$ & $496(43)$ & $136(38)$ & $132(49)$ & $82(42)$ & $64(42)$ & $52(36)$ & $4(9)$ & - \\
\hline $9 \cdot W$ & $334(42)$ & $128(31)$ & $210(32)$ & $138(38)$ & $110(28)$ & $108(37)$ & $48(23)$ & $86(44)$ & - \\
\hline $15-N$ & $56(27)$ & $46(38)$ & $34(35)$ & $56(39)$ & $52(43)$ & $26(46)$ & $34(44)$ & $12(21)$ & - \\
\hline $15-S$ & $144(33)$ & $80(34)$ & $78(41)$ & $18(25)$ & $18(28)$ & $28(21)$ & $12(16)$ & $8(14)$ & - \\
\hline $15-E$ & $228(45)$ & $200(52)$ & $96(44)$ & $34(24)$ & $30(23)$ & $8(11)$ & $18(26)$ & $8(19)$ & - \\
\hline $15-W$ & $42(30)$ & $60(48)$ & $26(39)$ & $44(46)$ & $46(37)$ & $22(26)$ & $20(31)$ & $12(19)$ & - \\
\hline
\end{tabular}

$-=$ traps not placed at this distance.

Dispersal of Seed in Clearcut Units
Total seed and filled seed dispersed into opening differed greatly with source area (table 4). Mean number of filled seed per square meter was 385 in unit 1, 1,430 in unit 9 , and 399 in unit 15 . There was little apparent relation between the number of seeds collected and the size of the seed source area: 9-S and 9-W produced similar numbers of both total and filled seed, yet 9-W was a narrow strip and 9-S was a large block of white spruce. Conversely, source area $9-\mathrm{N}$ also was a narrow strip, yet it produced more seed. 
The amount of filled seed trapped in each clearcut unit declined gradually but not uniformly with distance from the assumed source area (table 4). Because of variability in production by source area (table 2), dispersal along the transect was expressed as a ratio of the number of filled seeds per square meter collected at different distances in the unit to production of filled seed in the source area. The following two equations were used to model the seed dispersal data:

$$
\begin{aligned}
& Y=0.463 \exp ^{(-0.019 X)}, \text { and } \\
& Y=\exp ^{(-0.044 X)}
\end{aligned}
$$

where

$Y=$ dispersal of filled seed into openings relative to production of filled seed in source areas, in percentage; and

$X=$ distance from source area, in meters.

The asymptotic standard error for the intercept term (bo) in equation (3) was 0.058 ; the asymptotic standard error for the coefficient of the independent variable $\left(b_{1}\right)$ in both equations was 0.003 . The weighted root mean square was 0.328 for equation (3) and 0.391 for equation (4). There were 92 observations.

The negative exponential model seemed to fit the data adequately (fig. 3), and the model performed logically, with an approximately exponential decay in percentage of seed dispersed with increasing distance from the seed source. The model with bo set to 1.0 (equation 4) did not seem to fit the data as well as the model with bo estimated from the data (equation 3). In fact, the hypothesis that bo was equal to 1 was rejected $(p<0.01)$ by using the likelihood ratio test described by Gallant (1975). Although it may be logical for bo to be 1.0 when distance is zero, data were not collected for distances less than 10 meters. Based on plots of both the data and the models (fig. 2), we recommend using the model with bo equal to 0.463 as estimated from the data (equation 3). This model should be used only for distances greater than 10 meters, however. Possible explanations for why the model based on equation (4) does not fit well are (1) there is a radical change in model form for distances between 0 and 10 meters, possibly including the effects of microenvironmental factors such as increased turbulence and wind eddies near the edge of opening; or (2) there is a large discontinuity in the model at a distance of zero.

The shape of the dispersal curve was similar for most units and transects, although the total number of seed dispersed differed greatly among units. In general, distribution of seed across openings suggested little apparent relation to direction of wind. From equation (3), 126 filled seed per square meter at 20 meters and 72 filled seed per square meter at 50 meters from an uncut seed source could be expected if the source area produced 400 filled seeds per square meter (fig. 3). Number of seeds dispersed gradually declined between 10 and 120 meters; at 120 meters from the source, the amount of seed collected was less than 5 percent of estimated seed fall in the source area. Previous work on this same island indicated that successful germi nation and survival of white spruce seedlings for 3 years occurs for only 13 to 28 percent of the seed sown on prepared mineral soil (Youngblood and Zasada 1991). From this relation and equation (3) with 400 seeds per square meter in the source area, four to six seedlings per square meter could be expected at 120 meters into 


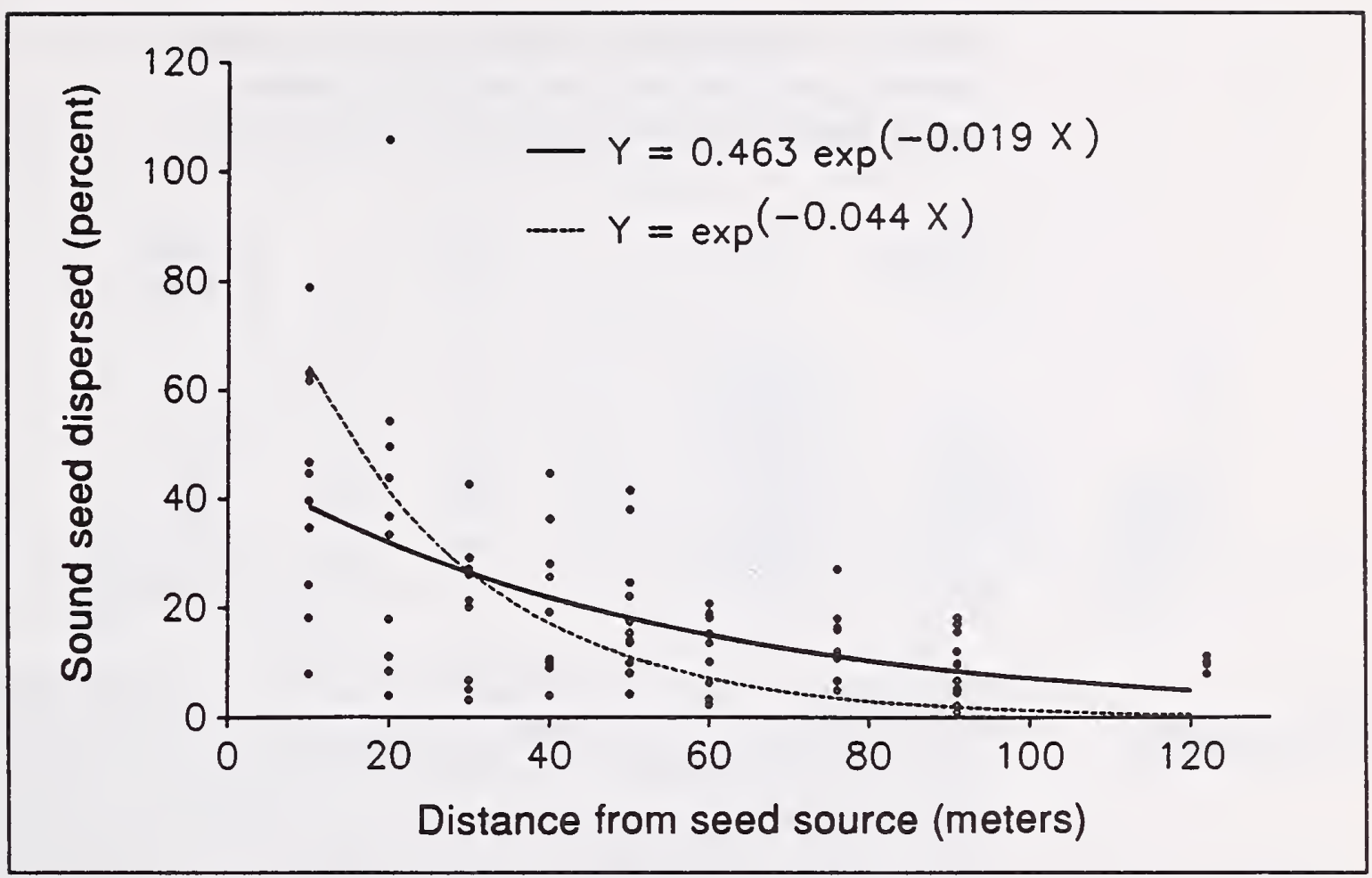

Figure 3-Dispersal of filled seed (expressed as a ratio [X 100] of seed collected in harest openings to production of filled seed in uncut stands) as a function of distance from seed source. Esimates from equations (3) and (4) are presented.

the opening. Beyond this distance, successful dispersal of seed and establishment of seedlings would be unlikely. Likewise, less than two seedlings per square meter may become established on unscarified seedbeds (organic surfaces) at distances of 40 meters or more from a seed source.

It is difficult to directly compare dispersal of white spruce seed in interior Alaska with dispersal reported elsewhere. Dobbs (1976) estimated about 2,550 total white spruce seed per square meter in an uncut stand near Prince George, British Columbia, an area similar to source area $9-W$ in our study. He predicted about 700 total seeds per square meter at 50 meters from one stand edge by using a quadratic equation and data from three parallel transects. Forty-eight percent of his seed was filled. He also found greater dispersal during the winter months and suggested the possibility of transport of seed across a hardened snowpack. Only in source area 9-N was production of seed greater on Willow Island than that reported by Dobbs (1976).

Dispersal of white spruce seed in three upland stands near Willow Island was observed in 1983 (Zasada 1985). The number of viable seeds at 50 meters from a source averaged 9 percent of the production of viable seeds within the stand; this value declined to under 6 percent at 100 meters from the source. In contrast, our equation (3) predicted 18 percent of source area production of filled seed at 50 meters and 7 percent at 100 meters. Use of germination tests may account for differences in seed quality.

Based on early work in Canada, McCaughey and others (1986) rated white spruce about 15 percent more efficient in dispersing seed than Engelmann spruce (Picea engelmannii Parry ex Engelm.). Our white spruce dispersal model (equation 4), predicted, however, nearly equivalent dispersal results to their model for Engelmann spruce, a species typically found on sites where strong winds during seed-dispersal periods are common. 
Table 5-Production of total and fllled white spruce seed per square meter by shelterwood unlt on WIIlow Island for $1987(n=6)$

Seed Fall in Shelterwood Stands

Seasonal Wind Patterns

\begin{tabular}{lrrrrr}
\hline $\begin{array}{l}\text { Source } \\
\text { area }\end{array}$ & $\begin{array}{l}\text { Total } \\
\text { seed }\end{array}$ & SE & $\begin{array}{l}\text { Filled } \\
\text { seed }\end{array}$ & SE & $\begin{array}{l}\text { Percent } \\
\text { of total }\end{array}$ \\
\hline 5 & 288 & 16 & 141 & 13 & 49 \\
8 & 174 & 21 & 61 & 10 & 35 \\
11 & 735 & 165 & 192 & 29 & 26 \\
14 & 723 & 228 & 240 & 51 & 33 \\
\hline
\end{tabular}

Production of seed, as expected, was less in shelterwood stands than in undisturbed stands (table 5). Total seed fall ranged from 174 to 735 seeds per square meter across four shelterwood harvest units; filled seeds made up 33 percent of this seed fall. Nevertheless, seed fall per unit basal area was similar to uncut source areas: white spruce basal area in shelterwood stands averaged 34 percent of that in uncut source areas, and production of filled seed averaged 40 percent of that in source areas.

The seasonal distribution of seed fall in shelterwood stands was similar to that of undisturbed stands; 65 percent of the filled seed produced in these shelterwood stands fell before mid-October, and 59 percent of the total seed fall occurred after this date (fig. 4). Both stands 11 and 15, however, dispersed many filled seed during winter.

The wind pattern on Willow Island was strongly bimodal from mid-August through December; most of the wind was from either the northeast or south-southwest (fig. 5). The proportion of south-southwest winds diminished slightly during early winter, however, thereby leaving an even greater proportion of the wind from the north-northeast. Little or no wind occurred from the east, south, and northwest when seed was dispersed.

Mean wind speed was greatest from mid-August to mid-October and was associated with southwesterly winds. Wind speed decreased slightly during winter. Maximum daily wind velocities were consistently from the same direction as mean velocities.

Daily speed and direction of wind at the Fairbanks International Airport were similar to Willow Island (fig. 5). Again, the distribution was bimodal, with winds predominantly from either the north and north-northeast or the southwest. Wind speeds were slightly higher than those measured at Willow Island but were consistent in the pattern of occurrence and decrease during winter. 

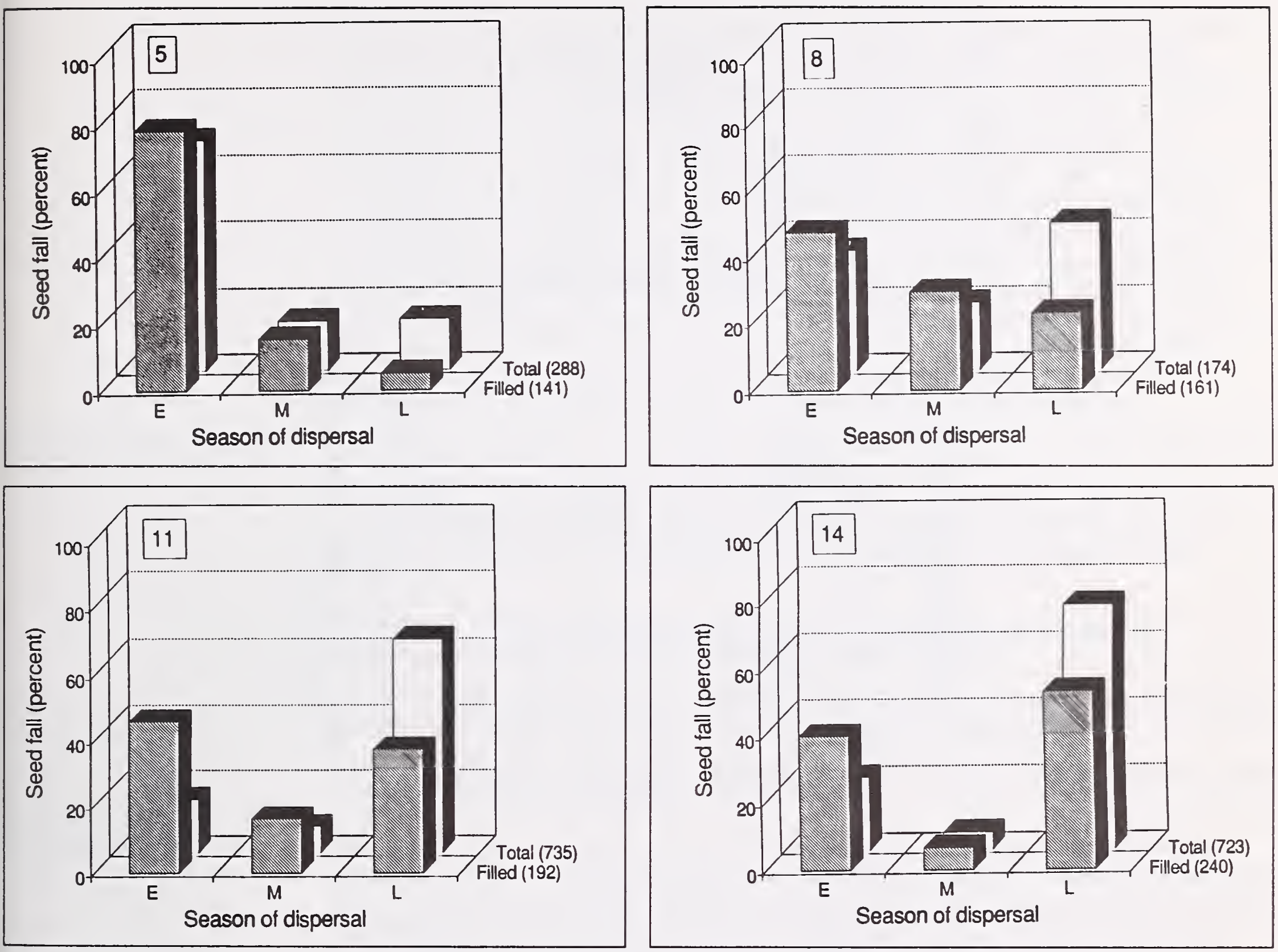

Figure 4-Timing of dispersal of white spruce seed for total and filled seeds, expressed as a percentage, for four shelterwood stands on Willow Island in 1987. Numbers in parentheses are basis, in seeds per square meter. $E=$ mid-August to mid-September; $M=$ mid-September to mid-. October; $L=$ mid-October to May. 


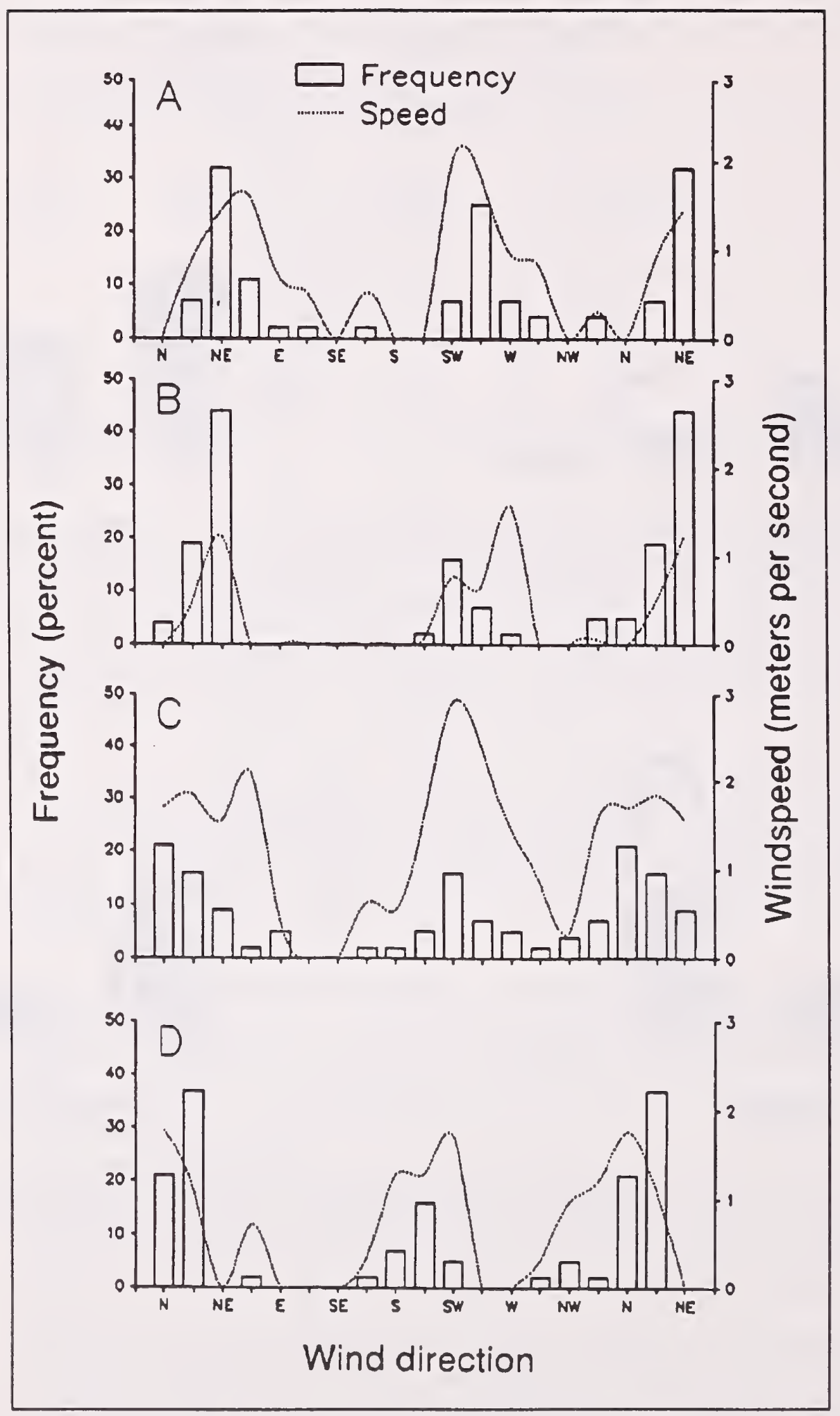

Figure 5-Directional frequency and average wind speed for (A) Willow Island from 11 August through 7 October 1987, (B) Willow Island from 19 November through 31 December 1987, (C) Fairbanks International Airport from 11 August through 7 October 1987, and (D) Fairbanks International Airport from 19 November through 31 December 1987. The arbitrary discontinuity at $360^{\circ} \mathrm{N}$ is avoided by duplicate plotting of three secors. 


\section{Recommendations}

\section{Conclusions}

\section{Acknowledgments}

Winds in interior Alaska are closely associated with large-scale atmospheric circulation patterns modified by local terrain features (Bowling 1980). During summer, storms move inland from the Gulf of Alaska and Bering Sea. Most of the wind and precipitation is blocked by mountain barriers and never reaches the interior. By August, however, low-pressure centers located near the Aleutian Islands usually have moved northward to the Bering Strait, thereby allowing onshore flow parallel to the Alaska Range. Both wind and precipitation increase in the interior with greater storm frequencies. By October, high pressure centers reestablish over eastern Siberia and north of the Yukon Territory, Canada, and are responsible for southerly flows. The Tanana River is the primary terrain feature responsible for modifying wind patterns; at low elevations, winds tend to follow the river drainage pattern. Thus, at the Fairbanks International Airport, winds follow the more north-south trending valley; long-term records indicate winds at Nenana (70 kilometers to the southwest) (Selkregg, n.d.), like Willow Island, are from the northeast and southwest.

Natural regeneration of white spruce on similar floodplain sites in interior Alaska may be enhanced under the following recommendations:

1. Forest managers should recognize the wide variability in total seed production of floodplain white spruce stands, even in years of apparently high levels of seed production.

2. Dispersal of seed across openings relative to seed production in sources surrounding openings can be predicted by using equation (3).

3. Clearcut openings should be oriented with the long axis in a northwest to southeast direction to maximize the effect of early season wind dispersal.

4. Seed trees should be retained for production and dispersal of seed in large harvest units.

Production of total and filled seeds in both uncut and shelterwood stands differed greatly and was not related to total basal area, basal area of white spruce, number of living white spruce stems per hectare, average d.b.h. of all trees, and average height of dominant trees. The mean ratio of filled seed to total seed in uncut stands was 0.29 . Most filled seed fell early in the dispersal season. Dispersal into clearcut openings declined gradually but not uniformly with distance from the source areas and was modeled with a negative exponential decay function. Winds during the dispersal season were strongly bimodal in direction; most winds were either from the northeast or south-southwest. Additional work is necessary to relate number of filled seed necessary for full stocking on different seedbed types.

We thank C. Teutsch for hours devoted to counting seed and J. Alden, B. Beebe, G. Lessard, C. Maisch, D. Perala, L. Viereck, J. Zasada, and R. Souter for providing helpful comments on an earlier draft.

Alden, J. 1985. Biology and management of white spruce seed crops for reforestation in subarctic taiga forests. Bull. 69. Fairbanks, AK: University of Alaska-Fairbanks, Agricultural and Forestry Experiment Station. $51 \mathrm{p}$.

Bowling, Sue Ann. 1980. The weather and climate of Alaska. Weatherwise. 33: 197-201.

Cochran, W.G. 1977. Sampling techniques. 3d ed. New York: John Wiley and Sons. $428 \mathrm{p}$. 
Dobbs, R.C. 1976. White spruce seed dispersal in central British Columbia. The Forestry Chronicle. 52: 225-228.

Dyrness, C.T.; Vlereck, L.A.; Foote, M.J.; Zasada, J.C. 1988. The effect on vegetation and soil temperature of logging flood-plain white spruce. Res. Pap. PNW-RP-392. Portland, OR: U.S. Department of Agriculture, Forest Service, Pacific Northwest Research Station. 45 p.

Gallant, A.R. 1975. Nonlinear regression. The American Statistician. 29(2): 73-81.

Krlshnalah, P.R.; Rao, C.R., eds. 1988. Handbook of statistics. New York: Elsevier Science Publishing Co., Inc. 594 p. Vol. 6.

McCaughey, Ward W.; Schmidt, Wyman C.; Schearer, Raymond C. 1986.

Seed-dispersal characteristics of conifers in the inland mountain west. In:

Schearer, Raymond C., comp. Conifer tree seed in the inland mountain west: symposium proceedings; 1985 August 5-6; Missoula, MT. Gen. Tech. Rep. INT-203. Ogden, UT: U.S. Department of Agriculture, Forest Service, Intermountain Research Station: 50-62.

Nienstaedt, Hans; Teich, Abraham. 1972. Genetics of white spruce. Res. Pap. WO-15. Washington, DC: U.S. Department of Agriculture, Forest Service. 24 p.

Selkregg, Lidia L. [n.d.]. Alaska regional profiles, Yukon region. Anchorage: Arctic Environmental Information and Data Center, University of Alaska. 346 p. Vol. 6.

Slaughter, Charies W.; Viereck, Leslie A. 1986. Climatic characteristics of the taiga in interior Alaska. In: Van Cleve, K.; Chapin, F.S., III; Flanagan, P.W., eds. Forest ecosystems in the Alaska taiga: a synthesis of structure and function. New York: Springer-Verlag: 9-21.

State of Alaska. 1988. Tanana Valley State Forest management plan. Juneau, AK: Alaska State Department of Natural Resources, Division of Forestry. [Unconventional pagination].

Viereck, L.A.; Van Cleve, K.; Dyrness, C.T. 1986. Forest ecosystem distribution in the taiga environment. In: Van Cleve, K.; Chapin, F.S., III; Flanagan, P.W., eds. Forest ecosystems in the Alaska taiga: a synthesis of structure and function. New York: Springer-Verlag: 22-43.

Werner, R.A. 1964. White spruce seed loss caused by insects in interior Alaska. Canadian Entomologist. 96: 1462-1464.

Youngblood, Andrew P.; Zasada, John C. 1991. White spruce artificial regeneration options on river floodplains in interior Alaska. Canadian Journal of Forest Research. 21: 423-433.

Zasada, John. 1980. Some considerations in the natural regeneration of white spruce in interior Alaska. In: Murray, Mayo; VanVeldhuizen, Robert M., eds. Forest regeneration at high latitudes: Proceedings of an international workshop; 1987 November 15-17; Fairbanks, AK. Gen. Tech. Rep. PNW-107. Portland, OR: U.S. Department of Agriculture, Forest Service, Pacific Northwest Forest and Range Experiment Station: 25-29.

Zasada, John C. 1971. Frost damage to white spruce cones in interior Alaska. Res. Note PNW-149. Portland, OR: U.S. Department of Agriculture, Forest Service, Pacific Northwest Forest and Range Experiment Station. 7 p. 
Zasada, John C. 1985. Production, dispersal, and germination of white spruce and paper birch and first-year seedling establishment after the Rosie Creek fire. In: Juday, Glenn P.; Dyrness, C. Theodore, eds. Early results of the Rosie Creek fire research project-1984. Misc. Publ. 85-2. [Fairbanks, AK]: University of Alaska-Fairbanks, School of Agriculture and Land Resources Management, Agriculture and Forestry Experiment Station: 34-37.

Zasada, John C.; Foote, M. Joan; Deneke, Frederick J.; Parkerson, Robert H. 1978. Case history of an excellent white spruce cone and seed crop in interior Alaska: cone and seed production, germination, and seedling survival. Gen. Tech. Rep. PNW-65. Portland, OR: U.S. Department of Agriculture, Forest Service, Pacific Northwest Forest and Range Experiment Station. 53 p.

Zasada, John C.; Lovig, Donald. 1983. Observations on primary dispersal of white spruce, Picea glauca, seed. Canadian Field-Naturalist. 97: 104-106.

Zasada, John C.; Viereck, Leslie A. 1970. White spruce cone and seed production in interior Alaska, 1957-68. Res. Note PNW-129. Portland, OR: U.S. Department of Agriculture, Forest Service, Pacific Northwest Forest and Range Experiment Station. $11 \mathrm{p}$. 

Youngblood, Andrew; Max, Timothy A. 1992. Dispersal of white spruce seed on Willow Island in interior Alaska. Res. Pap. PNW-RP-443. Portland, OR: U.S. Department of Agriculture, Forest Service, Pacific Northwest Research Station. $17 p$.

The seasonal and spatial patterns of dispersal of white spruce (Picea glauca (Moench) Voss) seed were studied from 1986 to 1989 in floodplain stands along the Tanana River near Fairbanks, Alaska. Analysis of the 1987 crop showed that production of filled seed was strongly related to estimated production of total seed and unrelated to selected stand structural characteristics. A mathematical expression, developed to estimate dispersal of filled seed into clearcut openings, predicted dispersal between 10 and 120 meters from the edge of an opening. The pattern of wind during the seed-dispersal season was predictable and consistent with winds measured at the Fairbanks International Airport. The results give forest managers ways to increase natural regeneration of white spruce in interior Alaska.

Keywords: White spruce, Picea glauca, dispersal of seed, Alaska (interior), production of seed, wind pattern.

The Forest Service of the U.S. Department of Agriculture is dedicated to the principle of multiple use management of the Nation's forest resources for sustained yields of wood, water, forage, wildlife, and recreation. Through forestry research, cooperation with the States and private forest owners, and management of the National Forests and National Grasslands, it strives-as directed by Congress-to provide increasingly greater service to a growing Nation.

The U.S. Department of Agriculture is an Equal Opportunity Employer. Applicants for all Department programs will be given equal consideration without regard to age, race, color, sex, religion, or national origin.

Pacific Northwest Research Station

333 S.W. First Avenue

P.O. Box 3890

Portland, Oregon 97208-3890 
U.S. Department of Agriculture

Pacific Northwest Research Station

333 S.W. First Avenue

P.O. Box 3890

Portland, Oregon 97208

Official Business

Penalty for Private Use, $\$ 300$ 